\title{
THE PLEASURE OF EXCHANGE: ADAM SMITH'S THIRD KIND OF SELF-LOVE
}

BY

MICHELE BEE

This article argues that the self-love that motivates exchange in The Wealth of Nations (WN) can be seen as the desire for deserved approval discussed by Adam Smith in The Theory of Moral Sentiments (TMS). This often overlooked desire appears in TMS as the most representative kind of self-love. Exchange motivated by this desire emerges as the way to find confirmation through others' appraisal of one's own self-assessment, and thus to find an agreed-upon measure for respective deserved praise. The target in this economic relationship is that equivalence that signals mutual recognition of deserved esteem. Equivalence here is the aim and not the result of exchange, unlike a tug-of-war, where both parties try to give as little and gain as much as possible regardless of the recognition each deserves.

\section{INTRODUCTION}

In The Wealth of Nations (WN), Adam Smith explains the motive for exchange in terms of self-love, but there is no discussion of the principle in that context. This article explores how Smith's account of self-love in The Theory of Moral Sentiments (TMS) helps us explain the motive for exchange in $W N$. The reading presented in this article is based on the idea that self-love in Smith's work could have a meaning linked mainly to the principle of approval, and focuses on the neglected notion of self-love as desire for deserved approval. The article explores what happens when we interpret self-love in this

Michele Bee, Centre Walras Pareto, University of Lausanne. Email: michele.bee@unil.ch. For their invaluable advice I owe thanks to Vivienne Brown, Rob Garnett, Charles Griswold, Samuel Fleischacker, Christel Fricke, Jimena Hurtado, Maria Pia Paganelli, Reinhard Schumacher, Rudi Verburg, and Jeffrey Young, as well as the participants in the 2014 ESHET and the 2014 HES annual meetings. Many thanks to Roberto Baranzini, Pascal Bridel, Nicolas Brisset, Maxime Desmarais-Tremblay, Nicolas Eyguesier, Biancamaria Fontana, Harro Maas, Antoine Missemer, Thomas Müller, Simone Zurbuchen, and all my colleagues at the Centre Walras Pareto as well as my students at the University of Lausanne and Neuchâtel for their very helpful comments. I am especially grateful to Raphaël Fèvre for our enduring discussions and his precious suggestions. I am also indebted to Massimo Amato, Luca Fantacci, Luigi Doria, Alexandre Schild, and Graham Sells for their observations and encouragements, and to the anonymous referees for their insightful remarks. The usual disclaimer applies.

ISSN 1053-8372 print; ISSN 1469-9656 online/21/01000118-140 @ The Author(s), 2021. Published by Cambridge University Press on behalf of The History of Economics Society. This is an Open Access article, distributed under the terms of the Creative Commons Attribution licence (http://creativecommons.org/licenses/by/4.0/), which permits unrestricted re-use, distribution, and reproduction in any medium, provided the original work is properly cited. 
way in the description of exchange in $W N$. Exchange based on this desire can emerge as the way to find confirmation in others' evaluations of one's own evaluations, and thus to find an agreed-upon yardstick for respective deserved praise. The goal in this kind of exchange is not to give as little and gain as much as possible regardless of the praise each deserves, but to attain an equivalence that reveals mutual recognition of deserved approval.

The connection between self-love and approval has already been pointed out in discussions of Smith's intellectual context (see Hirschman 1977; Force 2003). However, scholars have understood Smithian self-love above all in terms of Jean-Jacques Rousseau's amour-propre or Bernard Mandeville's vanity and love of domination, i.e., the deceitful pursuit of others' approval at all costs (see Winch 1978; Skinner 1992; Lewis 2000; Kalyvas and Katznelson 2001; Force 2003; Dupuy 2006; Diatkine 2010; Luban 2012). ${ }^{1}$ From this perspective, exchange would simply be a means to impose on others, in the sense of persuading others to give us what we want by simulating an interest in what they want. Their agreement to our proposal would in itself fulfil our desire for the approval of others (see Force 2003). In this sense, exchange would be sought for the pleasure of having persuaded the others (see Young 1997; Dellemotte 2005; Walraevens 2010). In this article, this "pleasure of exchange" is understood, rather, as the pleasure of having persuaded the others that we really deserve their approval, and thus as the pleasure of having obtained their deserved esteem. All Smith's criticisms of Mandeville's self-love present in $T M S$ are taken into account here. In particular, it is considered that besides self-love as Mandevillian vanity (or love of praise), two other kinds of selflove are relevant in Smith's thought: self-love as love of praiseworthiness and self-love as love of deserved approval (see also Hanley 2009). ${ }^{2}$

Scholars generally consider love of praise and love of praiseworthiness as two kinds of human desires examined in TMS, the latter restraining the former (see, among others: Macfie 1967; Young 1997; Griswold 1999; Fleischacker 2004; Raphael 2007; Hanley 2009; Walraevens 2010; Forman-Barzilai 2010). In this sense, the more or less moderate love of praise would be the lowest and most common form of self-love, while the pure love of praiseworthiness would be the highest and wisest kind of self-love. The stress is always on the contrast between two extreme kinds of self-love, love of praise and love of praiseworthiness (see also McHugh 2016 and 2018). On the other hand, the third kind of self-love-understood as the love of deserved praise-is usually overlooked in the current literature, while Smith seems to see it as the most representative kind of self-love.

The motive for exchange based on this desire can be seen as the pursuit of that equivalence in exchange that satisfies the common desire for deserved approval. In this sense, each party in exchange thinks of the desire of the other party, because only when both parties are able to satisfy the desire for deserved approval can each party fulfil this desire.

With this reading we are not only outside the interpretations of Smith's exchange based on the more or less moderate desire for others' approval but also beyond the frame of an enlarged version of self-interest, which is Philip Wicksteed's “non-tuism." Smith's

\footnotetext{
${ }^{1}$ See instead Griswold (2017). On Mandevillian individuals' need for approval, see Hundert (2003) and Verburg (2015).

${ }^{2}$ On self-love as love of praiseworthiness, see also Mehta (2006).
} 
self-love is often seen as a "tacit" version of non-tuism (Heath 2013, pp. 257-258) 3 because this concept eliminates some possible ambiguities of the term "self-interest." Non-tuism does not imply people engaging in exchange as purely self-interested, in the sense of having in mind only themselves: it extends the idea of self-interest by including also the possibility of having in mind everyone but the other party in exchange. As Wicksteed wrote: "The economic relation does not exclude from my mind everyone but me, it potentially includes every one but you" (1910, p. 174). Non-tuism is taken as a valid explanation of Smith's exchange not only for scholars who deny any presence of sympathy or imaginary change in position in exchange (such as Brown 1991, 1994a, 1997) but also for those who accept an imaginary change of position in exchange through sympathy and the moderating role of the impartial spectator (see Fleischacker 1999, 2004; see also Fontaine 1997; de Jonge 2012). ${ }^{6}$ The parties in exchange that moderate their own desires through self-command (such as in Young 1997; Witztum 1998; Griswold 1999; Darwall 2004; Paganelli 2010) have the other party in mind but only strategically in order to reach an agreement (Fontaine 1997; Fleischacker 2004; Dellemotte 2005; Walraevens 2010), and make "a good bargain" (Wicksteed 1910, p. 180). ${ }^{7}$ Accordingly, they are still non-tuist in Wicksteed's sense. The aim of this article is not to deny non-tuism as a way of explaining Smith's self-love, but to argue that "exchange" in $W N$ can also be read as an economic transaction where each party really thinks of the other party, without bringing benevolence into the argument as well.

The first part of the article clarifies the distinction between the three kinds of self-love in $T M S$, and shows how we can consider the desire for deserved approval as the most representative form of self-love. In the second part, this kind of self-love is proposed as the motive for exchange presented in the opening pages of $W N$ (I.ii.2). Thus, a possible understanding of exchange in $W N$ other than that based on non-tuism and the approval of others will emerge. Given this explanation of exchange, the last part of the article provides an account of the origin of exchange that Smith saw lying behind the process leading to commercial society but never explained in $W N$ itself.

\footnotetext{
${ }^{3}$ Interpretations that diverge quite considerably in other respects embrace this view of Smith's self-love. See, for example, Wilson (1976), Brown (1994a), Robbins (1998), Fontaine (2000), Fleischacker (2004), Steedman (2010), de Jonge (2012), and Brennan and Moseley (2013).

${ }^{4}$ See Fleischacker (2004, p. 90). See also Brennan and Buchanan, who state that the person who intends to "maximize his own interests (or the interests of those for whom he acts) objectively defined ... need not be inherently self-interested in some personalized sense. As Wicksteed noted, 'non-tuism' is all that is required here" (1981, p. 156).

5 According to Wicksteed, what characterizes exchange as economic relation is not that I have in mind only myself (ego), since I can also think of other persons in general (alteri), but that I do not think of you $(t u)$ as the other party in exchange: "The specific characteristic of an economic relation is not its 'egoism' but its 'nontuism"” (1910, pp. 179-180). On this point, see also Steedman (1989), Fontaine (2000, pp. 411-412), Drakopoulos (2011, p. 466), and Bruni (2006, pp. 113-118).

${ }^{6}$ Expounding his reading of Smith's exchange through sympathy and the impartial spectator, Fleischacker writes: "Stigler would have been much closer to the truth had he described WN as "a stupendous palace erected upon the granite of non-tuism"” (2004, p. 294). Stigler's famous sentence is: "The Wealth of Nations is a stupendous palace erected upon the granite of self-interest" (1971, p. 265).

${ }^{7}$ Note that when Wicksteed (1910) denies the presence of sympathy in exchange, he uses this term in the sense of "benevolence" and not in the sense of Smithian sympathy. For the difference between benevolence and sympathy in Smith, see Raphael and Macfie (1976). Wicksteed (1910, p. 180) includes in non-tuist relations the possibility of taking the other's interest into account in order to make a good bargain.
} 


\section{DESERVED APPROVAL AS THE MOST REPRESENTATIVE KIND OF SELF-LOVE}

To lay the ground for discussion of the desire for deserved approval as the motive for exchange in $W N$, we need to distinguish it from two opposite and extreme kinds of selflove: love of praise and love of self-approval. To this end, we first need to see how Smith in $T M S$ develops a new approach to self-love by criticizing Mandeville. ${ }^{8}$

In the first section of $T M S$, Smith refers to those, like Mandeville, who are "fond of deducing all our sentiments from certain refinements of self-love" (TMS I.i.2.i; emphasis added). For Smith the problem does not lie so much in the fact that Mandeville deduces all sentiments from self-love as that he refines self-love to the point of reducing it to a single desire that embraces every other possible form of it: "Dr. Mandeville considers whatever is done from a sense of propriety, from a regard to what is commendable and praise-worthy, as being done from a love of praise and commendation, or as he calls it from vanity" (TMS VII.ii.4.7). Thus, when Smith finally criticizes Mandeville towards the end of TMS, he defines-as Ryan Hanley (2009) also argues-three different forms of self-love. ${ }^{9}$ These kinds of self-love are described in the following statement, where Smith sets out to explain why, unlike Mandeville, he believes that "self-love may frequently be a virtuous motive of action" (TMS VII.ii.4.8; emphasis added): "I shall only endeavour to show that the desire of doing what is honourable and noble, of rendering ourselves the proper objects of esteem and approbation, cannot with any propriety be called vanity. Even the love of well-grounded fame and reputation, the desire of acquiring esteem by what is really estimable, does not deserve that name" (TMS VII.ii.4.8).

The former kind of self-love is vanity (or love of praise): "the frivolous desire of praise at any rate" (TMS VII.ii.4.9), that is, the Mandevillian desire to gain the approval of the others. The latter is love of virtue (or love of praiseworthiness): "the desire of rendering ourselves the proper object of honour and esteem; or of becoming what is honourable and estimable" (TMS VII.ii.4.9), that is, the desire to achieve self-approbation. ${ }^{10}$ The third kind of self-love is love of true glory (or love of deserved praise): "the desire of acquiring honour and esteem by really deserving those sentiments" (TMS VII.ii.4.9), that is, the desire to gain the deserved approval of others. ${ }^{11}$

\footnotetext{
${ }^{8}$ In the present article Mandeville is approached through Smith's interpretation, since what counts here is the criticism Smith leveled against him. For an examination of Mandeville's position on the issues addressed in this article, see in particular Verburg (2015), Tolonen (2013), and Hundert (1994). Smith's criticism of Mandeville's conception of self-love should also apply to Rousseau (see Smith [1756] 1980; see also Griswold 2017; McHugh 2018), regardless of the differences between Mandeville and Rousseau. On recent scholarship on Smith and Rousseau, see Paganelli, Rasmussen, and Smith (2018).

9 Hanley suggests an "ascent of self-love in three stages" and connects them respectively to prudence, magnanimity, and beneficence (2009, pp. 92-99).

${ }^{10}$ See also Fleischacker (2004, p. 66), who suggests that love of virtue can be understood as a kind of selflove.

${ }^{11}$ See also Bee (2014) and McHugh (2016 and 2018), where, however, the focus is more on the difference between love of virtue and vanity than on love of true glory and its distinction from both vanity and love of virtue, as it is in this article. See Walraevens (2019) for vanity possibly entailing love of true glory, and especially on the difference between vanity and pride.
} 
The difference between vanity and love of virtue, i.e., between love of praise and love of praiseworthiness, is quite evident. In Smith's terms, the former consists in the pursuit of others' sympathy ${ }^{12}$ for its own sake; the latter, in the pursuit of the sympathy of our imaginary impartial spectator (that is, the impartial judge of ourselves). ${ }^{13}$ However, as Smith also points out (TMS VII.ii.4.9-10), this is not the case with the difference between love of true glory and vanity or between love of true glory and love of virtue. This is due to the fact that vanity and love of virtue are diametrically opposed, while love of true glory is midway between them and so contiguous with both. Vanity is different from love of true glory (or deserved approval), because in the latter case the approval of the others needs to be deserved. Love of virtue (or self-approval) is different from love of true glory, because the desire to be the "proper object" of approval does not necessarily imply the desire to "acquire" that approval, as in the latter case. Love of praiseworthiness is the love of being worthy of praise for its own sake, independently of the others' approval; love of deserved approval, instead, is the love of obtaining the others' esteem but, unlike vanity, only when it is really deserved. In other words, self-love as vanity means the pursuit of others' approval without caring about one's praiseworthiness; self-love as self-approval means the pursuit of the approval of one's impartial spectator without caring about the others' approval, while self-love as deserved approval means the pursuit of others' approval that concords with the approval of one's impartial spectator. Thus, even if it is correct to highlight - as most commentators do - the difference between love of praise and love of praiseworthiness, we still need to stress their difference from the love of deserved praise, which represents another and specific desire.

Having identified these three kinds of self-love in $T M S$, it is worth stressing that for Smith, vanity and love of virtue are two opposite and extreme kinds of self-love, limited to an exiguous minority of circumstances or persons. Although all mature persons achieve the capacity for self-judgment, according to Smith only the wisest are at all times able to find satisfaction in their self-approbation alone, without any recognition from others (TMS VII.ii.4.10). At the same time, only the poorest in spirit are most of the time deaf to their impartial spectator and in constant need of the vain approbation of others (TMS VII.ii.4.10; see also Young 1997, p. 47; Fleischacker 2004, pp. 104-120; Rasmussen 2008, p. 118).

As Smith writes in TMS: "They are the most frivolous and superficial of mankind only who can be much delighted with that praise which they themselves know to be altogether unmerited. Unmerited reproach, however, is frequently capable of mortifying very severely even men of more than ordinary constancy" (TMS III.2.11). ${ }^{14}$ And

\footnotetext{
12 On the different meanings of the term "sympathy" consistent with the interpretation proposed here, see Haakonssen (1981, p. 51), and the distinction between "affective," "epistemic," and "normative" sympathy as well as between "social" and "moral" sympathy in Brown (2016). On the concept of sympathy in Smith, see also Broadie (2006).

${ }^{13}$ On the Smithian concept of the impartial spectator, see Raphael (2007). Smith explains how we can achieve impartiality, as distance from oneself, through comparison between imagination in visual perception and imagination in moral judgment (see TMS III.3.2). What matters here is not the kind of judgment and its origin but its partiality or impartiality. On the relationship between distance and impartiality in Smith, see Paganelli (2010). On internal debate and self-questioning, see Brown (2016, pp. 242-245). On the relationship between Smith's thought and Shaftesbury's idea of soliloquy, see Weinstein (2013, pp. 44-49).

${ }^{14}$ Smith also adds that "no man of middling good sense can derive much pleasure from the imputation of a laudable action which he never performed" (TMS III.2.15; see also Fleischacker 2004, p. 113). Furthermore,
} 
he continues: "Very few men can be satisfied with their own private consciousness that they have attained those qualities, or performed those actions, which they admire and think praise-worthy in other people; unless it is, at the same time, generally acknowledged that they possess the one, or have performed the other" (TMS III.2.28). Thus, even if people may at times find themselves in the situation of the wise or of the vain, the majority are moved-most of the time-by another motivation: desire for the deserved approval of others.

It is in the failure to distinguish among these three distinct aspirations, along with reducing them to one vice (vanity), that Smith finds fault with Mandeville. Smith, by contrast, sees self-love as a virtuous motive for action in the case of the latter two. Moreover, he believes that these two together occur far more frequently than the first, which is pursued only by weaker persons or in rare moments of weakness in everyday life. Smith therefore leads us to understand that, if we wish to use the same term for all three aspirations, then it must be recognized that self-love is frequently a virtuous motive for action (TMS VII.ii.4.8). Smith perceives these two forms of self-love as being the most frequent, inasmuch as they comprise what he holds to be the most common, namely, the love of true glory. Accordingly, Smith observes that "the desire of becoming the proper objects of this respect, of deserving and obtaining this credit and rank among our equals, is, perhaps, the strongest of all our desires" (TMS VI.i.3).

What human beings desire most is neither the approbation of others alone nor selfapprobation alone but a blending of the two: the approbation of others, which is considered to be deserved, since it chimes with one's own self-approbation. Smith observes that self-love as self-approval makes people "happy and contented" (TMS III.2.3), but he adds that "it greatly confirms this happiness and contentment" when we find that other people, viewing our own character and conduct "with those very eyes with which we, in imagination only, were endeavouring to view them, see them precisely in the same light in which we ourselves had seen them. Their approbation necessarily confirms our own self-approbation" (TMS III.2.3; emphasis added). This confirmation is important also because we know the difficulty of being completely impartial with oneself and the risk of "self-deceit" (TMS III.4). Note that the motivation of seeking the others' praise as confirmation of our praiseworthiness is not the same as pursuit of the others' praise moderated by our desire for praiseworthiness (which scholars generally refer to when they argue that people seek praise and praiseworthiness).

More than a normative moral elevation from vanity to love of true glory, and from love of true glory to love of virtue — as stated by Hanley (2009, pp. 92-99)—in TMS there seems to be an attempt to describe the desire for the approval of others and the desire for self-approval as two diametrically opposed and extreme aspirations, which combine in the desire for deserved approval as a third and more representative motive for action. $^{15}$

vanity principally affects people in "the superior stations of life" rather than most of the people living in "the middling and inferior stations of life" (TMS I.iii.3.5-8; see Young 1997, p. 47; Rasmussen 2008, p. 78).

${ }^{15}$ According to Hanley's view of the three ascending stages of self-love, vanity-and not deserved approval, as proposed here - should be the most common motivation for action (2009, pp. 94-96). On this moral progress and on vanity as the "typical passion" of commercial society, see also Walraevens (2019). On Smith's conviction that most people are not vain, see Young (1997, p. 47) and Fleischacker (2004, pp. 104120). 


\section{DESERVED APPROVAL AS THE MOTIVE OF EXCHANGE}

Having identified three kinds of self-love in $T M S$, we can see how the third kind offers an interpretation of exchange in $W N$ that goes beyond non-tuism and the desire for the others' approval. In his Lectures on Jurisprudence $(L J)$, Smith observes: "It is not from benevolence, as the dogs, but from selflove that man expects any thing" ( $L J$ B, pp. 219220; emphasis added). If dogs try to gain the benevolence of others by "fawning and flattering" ( $L J$ A, vi.44; see also WN II.ii.2), and so by playing on the others' love of approbation, human beings, instead, look to the others' self-love.

Implicitly, then, the self-love Smith speaks of in $W N$ is not appealed to through flattery; it does not, that is, correspond to the desire for praise to which Mandeville refers. At the same time, the self-love Smith is referring to in $W N$ cannot be understood as the desire for self-approval alone, which seeks no rewards from any others (see Hanley 2009). If reference to the two opposite forms of self-love - the love of others' approval or the love of self-approval- will not suffice for us to understand the motive of exchange in $W N$ (I.ii.2), we can instead assume that here Smith is referring to the stronger and more representative form of self-love, understood as the desire for the deserved approval from others. ${ }^{16}$

Most of us, according to Smith, have an interest in receiving confirmation of our selfapproval from others through their open recognition of the esteem we deserve.

This recognition can be revealed by the services or "good offices" that the others offer us in exchange for the services we offer to them. ${ }^{17}$ When we deserve a certain degree of praise from the others for being able to provide them with some services, they can display their appraisal through the services they offer us in exchange. In this way, they show how much they appreciate our services. Confirmation of having performed to others truly good offices (thus, confirmation that we deserve some praise) will not come from the flattery that other people might regale us with but from what they actually intend to give us in exchange.

When the others offer us something in exchange, they are revealing that they deem our services to be worth as much as theirs. Through this comparison we can explicitly know how much they esteem us for having performed those services. For example, in primitive society, if I spend two hours making an arrow that can be useful to others, they show me how much they appreciate my effort by giving me in exchange something they consider of similar value. If they are willing to give me in exchange only something that can be produced in less than half an hour of equal effort, this probably means that they think I have wasted my time and that I do not really deserve the praise that I may have thought I deserved, since the arrow could have been made faster or better. Instead, if they offer me something that they can provide in two hours of equal effort, it implies that they

\footnotetext{
${ }^{16}$ Since the impartial spectator is implicit in this form of self-love, we may assume that no explicit reference to the former was needed in the passages of $W N$ where Smith explains exchange through self-love. Alternatively, if self-love is interpreted as vanity moderated by the impartial spectator, the problem remains of explaining why Smith makes no explicit reference to the latter in WN. On this point, see Young $(1986,1997)$ and Brown (1994a).

${ }^{17}$ Smith says that we exchange "good offices" (WN I.ii.2-3; emphasis added). They are not "bad offices"; otherwise they would deserve not approval but disapproval. At the same time, they do not constitute "beneficence" (which calls for gratitude), because-even if beneficial for others-they are not offered as gifts.
} 
probably think that I have not wasted my time, and that they appreciate the quality of my arrow (as in fact I do, otherwise I would probably not have spent that time producing it). They therefore show approval of my performance and in a way encourage me to continue (while, in the previous case, they discourage me from doing so). In this way, I could decide to devote myself increasingly to this specific activity. If I excel in making the frame and cover of little huts, my neighbors will probably often ask for my help by offering me something in exchange that shows how much they appreciate my skill.

If I am a brewer in a commercial society and people mostly prefer other brewers, I would probably be discouraged from continuing since I do not find confirmation of my own self-assessment in their evaluation. On the other hand, if my clients are willing to pay even more for my beer than for other beers, this means that they really appreciate my ingenuity. ${ }^{18}$ If I am not a brewer but a client, the fact that I am able to buy beer shows to the brewer that I am not a beggar and that I deserved that beer because the services I provided to someone else were appreciated enough to allow me to buy that beer. When I negotiate my money for that beer, I am implicitly proposing or accepting an equivalence between the deserved approval I received for the services I provided to others (revealed by that amount of money) and the approval that I bestow on the brewer for that beer. If I do not buy the beer directly from the brewer but in a pub, it does not imply that exchange could not work in the way described here. The fact that I often go to that pub to buy that beer might mean that I appreciate not only how the beer is brewed but also how it is distributed (assuming, of course, that the brewer and the pub do not have monopolistic positions). Thus, exchange could take this form both for sellers and buyers, including when the buyers offer nothing but money for goods or services that the sellers may not even have produced themselves. In this case, when both parties agree on the equivalence of the exchange, it implies that each of them sees the other's esteem as a possible confirmation of their own self-assessment. Thus, exchange takes place when both parties can find satisfaction of their shared desire for well-deserved approval.

In this scenario, exchange does not necessarily take the form of a tug-of-war between two parties, each seeking to give as little and gain as much as possible regardless of the praise each deserves - which, however, is always a possibility (although hardly a way to win the deserved approval they wish for). ${ }^{19}$ If the interest of both parties is to obtain the approval they deserve, then what is primarily sought in exchange is precisely that very equivalence that it consists in (as desired confirmation of the esteem that each party deserves). ${ }^{20}$ Addressing the other's self-love in exchange (WN I.ii.2), then, could mean touching upon this desire by immediately proposing an equivalence: "Give me that which I want, and you shall have this which you want" (WN I.ii.2; emphasis added).

This kind of exchange comes about when both parties impartially balance their reciprocal interests in seeing the approval they deserve recognized. The impartial evaluation of interests can be achieved when each side is able to express their own

\footnotetext{
${ }^{18}$ The same could apply to teachers directly paid by students. This reading also helps us to understand better Smith's famous opposition to a fixed salary for teachers in $W N$ (V.i.f), since it would prevent exchange from being an incentive to either continue that profession or give it up.

${ }^{19}$ As in the case of the two sugar merchants in Mandeville's Fable (FB I, p. 50).

${ }^{20}$ In this sense, we could say that when Smith describes "a fair and deliberate exchange" in WN (I.ii.2), he is describing a deliberately fair exchange.
} 
evaluation as if consulting a third person, equidistant from both parties. ${ }^{21}$ In order to be able to balance our interests with those of the other, Smith observes, "we must view them, neither from our own place nor yet from his, neither with our own eyes nor yet with his, but from the place and with the eyes of a third person, who has no particular connexion with either, and who judges with impartiality between us" (TMS III.3.3; emphasis added). This third person is the impartial spectator.

Shortly before the passage quoted above, Smith observes: "It is only by consulting this judge within, that we can ever see what relates to ourselves in its proper shape and dimensions; or that we can ever make any proper comparison between our own interests and those of other people" (TMS III.3.1; emphasis added). This is how either party, rather than just moderating their own presumed partial interest, can impartially compare both respective interests. It is by consulting the imaginary impartial spectator that the parties to exchange can balance their respective interests and agree on an equivalence that satisfies their desire for deserved praise. ${ }^{22}$

But, as Smith observes, "it is often difficult to ascertain the proportion between two different quantities of labour. The time spent in two different sorts of work will not always alone determine this proportion. The different degrees of hardship endured, and of ingenuity exercised, must likewise be taken into account" (WN I.v.4). And he adds: "it is not easy to find any accurate measure either of hardship or ingenuity" (ibid.). Many factors need to be evaluated: for example, the training required, the trustworthiness, the risk, and the honorableness of the employments (see WN I.x.b; see also Young 1985). Since it is not easy to find any accurate measure of either hardship or ingenuity, Smith says, prices are determined by the "higgling and bargaining of the market" (WN I.v.4). ${ }^{23}$ If the rules for determining prices were as precise as "the rules of grammar" (as, for Smith, in the case of corrective justice, see TMS VII.iv.1), then there would be no room for any kind of discussion, and prices could be established independently of market negotiations, for example by the government. However, this can hardly be seen as the way Smith explains exchange and the determination of prices. As Vivenne Brown pointed out, when there are no precise rules for judging, judgment is "open to interpretation by the agent" (Brown 2016, p. 244), who has to judge impartially "all the different shades and gradations of circumstance, character, and situation" (TMS VI.ii.1.22). ${ }^{24}$

\footnotetext{
${ }^{21}$ For an analysis of the third position in TMS consistent with my reading, see Khalil (1990). The fact that each is capable of self-judgment does not imply that no one ever falls into self-deceit. On the possibility of selfdeceit based on the internal division, and the division between the past and the present forms of the impartial spectator, see Fleischacker (2011). Self-deception, for Smith, occurs above all in the presence of "violent emotions," when general rules come to our aid (see TMS III.4.3; see also Pack 1991, pp. 87-88). On selfdeceit see also Darwall (1988) and Walraevens (2019).

${ }^{22}$ In this respect, see also Fleischacker (2004, p. 94), who refers to a "mutual respect" between exchangers; see also Rothschild (2001). In this article, mutual respect is understood not only as recognition of the other's independence and freedom (on free mutual consent and mutual accountability in exchange, see Darwall 2004; 2006, pp. 47-48) but also as satisfaction of the common desire for deserved approval. Equality between exchangers is not only assumed as a basic condition for exchange (where a role is played by persuasion and not coercion) but also as a result of exchange (where the parties agree on an equivalence that recognizes the praise they deserve).

${ }^{23}$ Moreover, exchange is not conducted in the form of one gift for another, both accepted without discussion, but through negotiation.

${ }^{24}$ This also presupposes that "the agent is free to decide what to do, without coercion" (Brown 2016, p. 245), as it necessarily happens also in exchange (see Darwall 2004; 2006, pp. 47-48; Fleischacker 2004, p. 94).
} 
The process of judging described by Smith "is always local and situated, never from a cosmic standpoint" (Brown 2016, p. 245). In the same way, what Smith calls "natural price" corresponds to "the natural rates of wages, profit, and rent, at the time and place in which they commonly prevail" (WN I.vii.3; emphasis added).

Social rules represent the consensus emerging in society at a certain time and place as a result of a number of impartial judgments in specific situations (see Brown 2016). Similarly, natural price could emerge at a certain time and place as a result of a number of negotiations that gave rise to specific agreed-upon prices. Although these prices are not necessarily identical for similar services or goods (since no "accurate measure" exists to evaluate different kinds of labor), being the outcome of impartial judgments they will approximate one another "according to that sort of rough equality which, though not exact, is sufficient for carrying on the business of common life" (WN I.v.4). In this sense, when there is no excess of demand and supply in the market, the "higgling and bargaining" can give rise to agreed-upon judgments and thus to similar prices for similar services at a certain time and place, from which the natural price emerges. As Smith explains: "When the quantity brought to market is just sufficient to supply the effectual demand and no more, the market price naturally comes to be either exactly, or as nearly as can be judged of, the same with the natural price" (WN I.vii.11; emphasis added). ${ }^{25}$ The "effectual demand" is the demand of "those who are willing to pay the natural price," that is-following the reading proposed here-the demand of those who are willing to recognize the praise deserved for "raising, preparing, and bringing" the commodities to market, to thus pay rent and wages and make provision for profit at their natural rates. Jeffrey Young affirmed that the natural price can be based on the "spectator mechanism," arguing, "the natural price will be a consensus price which individuals and the spectator will view as fair in the sense of not causing injury to any party.... Smith grounds exchange value on a spectator-approved social consensus in the same way he grounds justice and morality in general. This consensus is arrived at through the "higgling and bargaining"" (Young 1986, pp. 375-376). In the exchange suggested here, people do not refer to the impartial spectator solely for the sake of respect for their property, and thus corrective justice (see Young 1986, 1997), ${ }^{26}$ but for the deliberate purpose of recognizing the praise deserved by both parties as a way to achieve the equivalence that satisfies the common desire for deserved esteem.

In this process, each party seeks to persuade the other that what they offer truly deserves the other's attention, making clear what they believe to be the true value of the

\footnotetext{
${ }^{25}$ When the quantity exceeds or falls short of the effectual demand, then the mechanism of supply and demand works in order to bring the actual price around the natural price (which is the outcome of "higgling and bargaining" when there is no excess of demand or supply in the market). Smith's natural price is not determined by the mechanism of supply and demand, which instead explains how, even when the actual price is not around the natural price (due to the excess of supply or demand), the market price tends toward the natural price. On this point, see Garegnani (1983, p. 312); see also Naldi (2013, p. 304), Roncaglia (2005, p. 143), and Aspromourgos (2009, pp. 83-87).

${ }^{26}$ See also Haakonssen (1981), Witztum (1997), Griswold (1999), Verburg (2000), and Fleischacker (2004) for some of the present positions on the widely debated issue of justice in exchange according to Smith, which will be the subject of a subsequent article by this author. On the importance of the system of natural liberty and free competition for the emergence of the natural price as the just price, see Walraevens (2014).
} 
advantage the other would enjoy. ${ }^{27}$ It is in this sense that we can understand what Smith means when he writes that in exchange with others we "never talk to them of our own necessities but of their advantages" (WN I.ii.2). Addressing the self-love of others and showing them their advantages involve our capacity to be other-directed. ${ }^{28}$ Showing others their advantages could be understood as simulating a concern for the advantages of the other exchangers in order to obtain their approval, as it appears at the beginning of the Fable of the Bees (FB I, p. 4) and in the passage from Rousseau's Second Discourse ([1755] 2008) translated and published by Smith ([1756] 1980) in his Letter to the Authors of the Edinburgh Review (see Force 2003, pp. 130-132; Rasmussen 2008, p. 79; Walraevens 2010, p. 17; Griswold 2018, p. 204). However, according to Smith it would be mortifying to succeed in gaining the approval of others without at the same time being aware of deserving it, as would gaining the credit from others without at the same time being aware of deserving it (TMS VII.iv.24). ${ }^{29}$ This does not mean that in exchange people cannot just "make it appear" that the others have an advantage (as Smith says in LJ A, vi.45; see also Walraevens 2010, p. 17), but simply that if we wish above all to obtain deserved credit and deserved approval, the motive for exchange should not be our own interest passed off as the interest of the other party. In this case, the motive is the desire to persuade the others that what we are giving is really worth what we are receiving in exchange. If praise has sense "as a proof of our own praiseworthiness," then-Smith explains clearly- "we never should endeavour to obtain it by unfair means" (TMS III.2.24). Otherwise, it would not constitute reliable proof and thus prove truly gratifying. ${ }^{30}$ In this sense, we would be fair not because we desired to obtain the approval of others without hurting them-thus moderating our desire for praise with our desire for praiseworthiness (e.g., Young 1997, Griswold 1999, Fleischacker 2004)—but rather because, otherwise, we could not consider the others' praise as proof of our praiseworthiness (which, in this case, is our motive for exchange).

Addressing others' self-love through the capacity to identify with them has often been understood as a means of devising a "strategy" — not necessarily deceitful — to obtain from others what interests us (Fleischacker 2004, pp. 90-99; see also Fontaine 1997,

\footnotetext{
${ }^{27}$ See also Lewis, who observes that, for Smith, succeeding in persuading others in exchange means "having what one makes or does recognized as valuable or useful to another" (2000, p. 289). This process takes placefor example, when we buy beer from the brewer or meat from the butcher- "so easily and so readily, that we are scarce sensible that we do it" (TMS III.3.3).

${ }^{28}$ See Young (1997), Fleischacker (1999, 2004), and Mehta (2006). Brown (1994a), instead, suggests that the "symmetry of the exchange relation" has no need "for an imaginary change of places or for sympathy" (p. 46). ${ }^{29}$ See also Griswold (2017, pp. 183-185), who writes that the "desire to be believed" is not "simply strategic" for Smith, even though he does not underline the essential difference between this desire and the desire to obtain deserved credit. On this point and for an interesting link between the desire to persuade or to convince and the rhetoric or the didactic discourse in Smith's Lectures on Rhetoric and Belles Lettres, see Walraevens (2010). See also Dellemotte (2005, pp. 67-71) and Brown (1994a and 1994b).

${ }^{30}$ If the motive for exchange is the desire for deserved approval, there can be no point in acting unfairly also with strangers (as instead in Viner [1972] 2015, pp. 80-82). Although some people can be moved by vanity, such as merchants building an empire for their own benefit, this is not necessarily the only motive for exchange, and perhaps not even the most representative, as instead the desire for deserved approval could be. On Smith accusing not the majority of people in commercial society of being deceitful but above all the wealthy merchants, see Rasmussen (2008, pp. 79-80). As Young writes: "No society can subsist in which the 'natural insolence of man', 'the rapacity, the monopolizing spirit of merchants' (WN IV.iii.c.9) or the 'pride of man' are the general tenor of conduct" (2001, p. 107).
} 
pp. 269-270; Dellemotte 2005, pp. 67-71; Walraevens 2010, p. 24). In this sense, nontuism would explain Smith's thought here. Samuel Fleischacker clarifies it thus: "I may not love my butcher and baker, I may indeed have no feelings for them at all, but to get what I want from them, I must at least moderate my self-centeredness down to the point at which I can present to them a plausible understanding of their needs and a willingness to help fulfill those needs" (1999, pp. 155-156). ${ }^{31}$ Moderation of self-love would allow us to come up with an acceptable and even attractive proposal (see Fleischacker 1999; see also Young 1986 and 1997; Fontaine 1997; Walraevens 2010). ${ }^{32}$ However, our motivation would remain the pursuit of our own interest, rather than the right balance between our own interest and that of the other party. ${ }^{33}$ This balance might possibly be the consequence of our strategic moderation but not our aim; so the motive for exchange is not this balance. This implies that self-love-even if moderate and understood as selfinterest and not as selfishness - could lead to obtaining from the exchange more than any impartial spectator would judge we deserve, because "the final outcome will depend on each one's negotiation or communication power" (Walraevens 2010, p. 27; see also Dellemotte 2005). Even in the case of dealers obliged to contain their self-love and to go beyond their partial and selfish position, we would have a seller "who wants to sell at the highest price" and a buyer that "wants to buy at the lowest price" (Walraevens 2010, p. 26). In this case, the final reason for the exchange is still the pursuit of one's own interest, and the imaginary change of position with the other person is the strategic means to "discover his preferences" and reach one's own ends through the agreement (Walraevens 2010, pp. 25-29; see also Fontaine 1997; Dellemotte 2005). As Wicksteed observed, what makes exchange an economic transaction is that "I am not considering you except as a link in the chain, or considering your desires except as the means by which I may gratify those of some one else-not necessarily myself" (1910, p. 174).

By contrast, the self-love corresponding to the desire for deserved approval does not need to be moderated and seeks just to satisfy the interests of both parties in exchange, without having to be considered a form of benevolence in consequence. ${ }^{34}$ If we assume that the self-love of the others represents their desire for deserved approval, then addressing it would mean recognizing the praise the other party deserves by proposing an exchange that reveals this recognition, and which at the same time recognizes the esteem we deserve. Thus, when Smith observes that we do not talk to others of our needs but of their advantages, he could well mean that we make the worth of our services explicit vis-à-vis those of the others. This would mean that what we offer others is not a deceitful proposal (as in Force 2003) or a just barely acceptable proposal (as in Fleischacker 2004) but a proposal that reflects what we really believe corresponds to the just balance of the rewards deserved by both parties to the exchange. In this sense, the accord will occur when both parties consider that the approval they deserve has been

\footnotetext{
${ }^{31}$ On non-tuism consistent with other-regarding attitudes, see also de Jonge (2012, pp. 17-19).

${ }^{32}$ In this sense, thanks to sympathy we would be able to understand the price the others are ready to pay (Walraevens 2014, p. 425).

${ }^{33}$ This pursuit of our own interest can include the interest of everyone but that of the other party in exchange, although we may take it into account strategically.

${ }^{34}$ For a reading of benevolence in Smith consistent with the understanding of self-love proposed here, see Garnett (2017).
} 
rightly recognized. ${ }^{35}$ On the other hand, if the evaluation of the counterparty remains distant despite reciprocal attempts at persuasion, then this kind of exchange does not take place at all-always a possibility. ${ }^{36}$

Exchange in $W N$ can thus be seen as an object of desire in itself, as satisfaction of the strong desire of deserved approval. According to Young, "Smith's emphasis on selfinterest does not preclude the operation of another motive in market activity, i.e. the desire for the approbation of the spectator" (1986, p. 369). Young refers to $L J$ (B, pp. 321-322) where Smith traces the propensity to exchange to the desire to persuade-and notices two different motives for exchange: self-interest and the "pleasure of agreement" (Young 1997, pp. 60-61). Instead, if we understand self-love as vanity or love of the others' approval and not as moderate self-love or self-interest, we have only one motive at work (as in Force 2003, pp. 130-132), which is the pleasure of having persuaded others. The reading proposed here suggests an alternative interpretation of this motive by focusing on the third kind of self-love: if we understand self-love as the desire to obtain deserved approval from others, then here too there is only one motive for exchange in operation, but we do not assume that Smith conceives of self-love as Mandeville or Rousseau do.

It is in this sense that here we can refer to the "pleasure of exchange." This pleasure is not understood here as the pleasure of agreement deriving from the pleasure of persuading others and thus of obtaining their approval, even when we do not hurt them (as in Young 1986, p. 369; 1997, pp. 60-61; Dellemotte 2005, p. 63; Walraevens 2010, p. 28). According to the reading proposed here, this pleasure derives from having been convinced by the offer of the others that they are truly persuaded that we deserve the appreciation they show us. It derives from the pleasure of persuading others that we truly deserve their praise, that is, of obtaining their deserved approval. In this sense, during the negotiations the parties to the exchange try to explain to one another the real worth of their mutual services, and to persuade each other of their respective deserved praise. The language of "higgling and bargaining" is therefore transparent-as Vivienne Brown points out (1994b) — because it does not distort the others' judgment through rhetorical imposition on them, and we do not need to suppose an "equal rhetorical power" between dealers (as instead in Walraevens 2010, p. 27). ${ }^{37}$ However, this does not imply that the "higgling and bargaining of the market" does not affect the determination of the price (as instead Brown 1994b has it). In the chapter devoted to the mechanism of supply and effective demand, Smith does not refer back to the "higgling and bargaining." But this is not because they have no effect on the determination of the natural price. On the contrary, it is the mechanism of supply and effective demand that has no effect on determining the natural price. This mechanism's only effect is in bringing the market price back to the natural price when the quantity supplied in the market is not quite enough to satisfy the effective demand. As already seen, the higgling and bargaining are crucial for the

\footnotetext{
35 This does not imply that in order to be able to exchange, all the people must at every moment of their life be in accord with themselves. Rather, it means being able to evaluate a specific deal impartially.

${ }^{36}$ This can also be the result of self-deceit, leading one or both exchangers to overestimate themselves, failing to pay heed to the just evaluation their imaginary impartial spectator makes of them (see TMS III.4). If we were dealing with a partial spectator, biased and deceived, this kind of exchange could not take place. Circumstances, however, can lead us to exchange even if we do not deem the other's assessment right.

${ }^{37}$ According to Walraevens: "People involved in the exchange must have equal rhetorical power; otherwise one of them will naturally use his superiority to get the greatest part of the surplus" (2010, p. 27; emphasis added).
} 
determination of the natural price because they can be seen as the result of a general consensus at a certain time and place that emerges from various negotiations approximating a similar price for similar services. However, it is also decisive because the higgling and bargaining allow us to find confirmation that the others are really persuaded that we deserve the praise they bestow on us. This desire to persuade others that we really deserve their esteem also accounts for the motivation that originally drove human beings to speech and to exchange.

\section{EXCHANGE BEFORE DIVISION OF LABOR}

Smith associates propensity to exchange - which gives rise to the division of labor - with the faculty of speech and the desire to persuade others (WN I.ii.2; LJ A, vi.56-57; Young 1986, 1997; Brown 1994b; Griswold 1999). This desire is often associated with the desire to persuade others as a way to impose one's superiority over them, an aspect that is present in Mandeville and Rousseau (Macfie 1967, p. 115; Kerkhof 1995, p. 232; Lewis 2000; Kalyvas and Katznelson 2001; Force 2003, pp. 129-134, Hurtado Prieto 2004, p. 18; Dellemotte 2005, p. 66; Walraevens 2010, pp. 15-16). ${ }^{38}$ Smith, however, speaks of superiority really worthy of admiration, in contrast to the "strong Desire Men have to triumph over, as well as persuade others" as conceived by Mandeville (FB II, p. 345).

At the end of $T M S$, Smith observes that just as individuals are satisfied only when they obtain the approval from others that they believe they deserve, so they are truly satisfied only when they obtain the credit they believe they deserve (see TMS VII.iv.24). If this credit is to be considered confirmation of one's self-evaluation, each must be convinced that the others too hold it to be truly deserved; hence, we will have a natural inclination to persuade others that we are creditworthy (for believing oneself to be creditworthy without the others' confirmation does not bring true satisfaction). This does not mean that people never try to persuade others even when they think they are mistaken $(L J \mathrm{~B}$, pp. 222-223; Walraevens 2010, p. 16). However, for Smith it is on the propensity to persuade others that we are really worthy of their credit that is "founded the faculty of speech" (TMS VII.iv.25). ${ }^{39}$

Smith argues that the origin of speech derives from "one of the strongest of all our natural desires," which consists in wishing to persuade others of one's own "real superiority" (TMS VII.iv.25; emphasis added). Smith sees speech as deriving from the desire to be truly believed and appreciated, or in other words to be considered creditworthy and praiseworthy also by the others (not only by oneself), and thus from regard for the truth. ${ }^{40}$

\footnotetext{
38 On language in Smith, see also Berry (1974), Otteson (2002), Swearingen (2013).

39 As the love for praise can be seen as the most common desire, and at the same time the desire for praiseworthiness as a desire of wise persons (Hanley 2009, pp. 94-96), similarly the desire to persuade others — even when we think we are mistaken — can be seen to characterize most people (also in exchange) but not "the man of virtue who has enough self command not to be corrupted" (Walraevens 2010, p. 16). Here, instead, following Smith's analogy between approval and credit, not only the desire for deserved approval but also the desire for deserved credit are considered the most common desires.

${ }^{40}$ This is probably why, in relation to the propensity to exchange in $W N$, Smith refers to the "faculty of speech or reason." For Smith, reason has to do with the distinction "between truth and falsehood" (TMS VII.ii.2.5).
} 
We can therefore argue that when Smith observes that the propensity to exchange derives from the faculty of speech (WN I.ii.2), as indeed from the desire to persuade others ( $L J$ A, vi.56-57), in both cases he could be referring to the inclination to seek from others the approval and credit we deserve.

Smith scholars have seen probity in exchange as the result of prudent regard for one's own interest - that is, self-love moderated by the desire to be worthy of credit—which induces sellers not to cheat when exchanges are frequent (e.g., Walraevens 2010, p. 21; Wells and Graafland 2012, p. 339). ${ }^{41}$ According to this reading, probity is a consequence of the frequency of exchanges, and not part of the motive for exchange (as, instead, suggested here). ${ }^{42}$ As Young observes, however, this reading would "make TMS a much more rationalistic theory than Smith intended" (1986, p. 374). When Smith refers to probity in $L J$ (B, p. 328), he "is here thinking specifically of a commercial state, showing why honesty and punctuality are so highly valued in such societies," but he is not "suggesting that these virtues have their origin in rational self-interest" (Young 1986, p. 374). According to Young, Smith does not account for mutual trust "on rationalistic grounds" related to "repetitive activity" but with "the desire to behave in a way which the impartial observer can sympathize with"; more than a consequence of the market, this desire is "necessary for the functioning of a market" (1986, p. 374). Going beyond Young's interpretation, behaving in a way that the impartial spectator can sympathize with not only has the role of limiting the action in order not to hurt the others and incur their disapproval, but it is part of the motive that drives to exchange. When the motive for exchange is the desire for deserved approval, we are not obliged to moderate our selflove while bargaining (driven by other motives: self-interest or others' approval) in order to preserve our honor and reputation: it is our (third kind of) self-love that makes us enter the exchange seeking the credit and approval we deserve. This last kind of exchange can take place independently of the frequency of exchange, and so also when people rarely exchange-as in the case of primitive people who start exchanging before bartering becomes a frequent activity.

The interpretation proposed here helps us to explain how exchange may originally have taken place in primitive society where, according to Smith, there is no gain through division of labor (which is represented as a consequence of the propensity to exchange in $W N$ ). In the absence of this gain, we can hardly assume that "the propensity to truck, barter, and exchange one thing for another" (WN I.ii.1) originates in the universal "desire of bettering our condition" (WN II.iii.28).

\footnotetext{
When he identifies the most representative form of self-love, he uses the idea of truth: he speaks of real superiority exactly as he speaks of love of true glory.

${ }^{41}$ In this sense: "The frequency of dealings is crucial here. When people seldom deal with one another, their reputation is not threatened. ... If merchants want to be approved, they need to be honest" (Walraevens 2010, p. 21). On the moral discipline of the free markets, see also Wells and Graafland (2012) and Walraevens (2014).

${ }^{42}$ For probity rewarded in commerce as a bourgeois virtue, see McCloskey (2006), Herzog (2013), Walraevens (2014). For "intense competition" undermining bourgeois virtues, see Wells and Graafland (2012). Note that Wells and Graafland (2012) consider the effects of intense competition on the basis of the principle that honesty is normally "the best policy," and thus that individuals prudently look to their own interest (and not that honesty, as it is proposed here, is something that is sought by people seeking deserved approval—not merely by wise people seeking self-approval).
} 
In the absence of material interest, the propensity to exchange could be seen as originating in the desire for the others' approval for its own sake. In this sense, exchange in primitive society would be based on self-love as desire for others' approval, which we can call "Mandevillian exchange." 43 The interpretation of exchange proposed here, and based on self-love as desire for deserved approval, does not rule out the possibility that the Mandevillian vain and selfish may engage in exchange, as the historical existence of the mercantile system demonstrates. According to Smith, mercantilism and Mandevillian exchange do not represent what commerce "ought naturally to be" (WN IV.iii.c.9). ${ }^{44}$ Nevertheless, in commercial society there is room for the natural selfishness of merchants building an empire for their own benefit, where commerce becomes "the most fertile source of discord and animosity" (WN IV.III.2; see Paganelli 2008). ${ }^{45}$ However, even if this natural selfishness and Mandevillian exchange can take place in commercial society, they cannot explain how exchange emerges in the early and rude state, giving rise to the division of labor and commercial society.

For exchange to take place, Mandeville deems it necessary for the division of labor, money, and a reference price system to be already in place. In the absence of these, i.e., in primitive society, natural discord amongst individuals would never allow them to come to agreement and so engage in exchange. They could look no further than mere survival, without enjoying the "reciprocal Services" which "are what Society consists in" and "are impracticable without Money" (FB II, p. 452). ${ }^{46}$ Even if the material interests were reduced to zero, as in the case of savages whose "Bellies were full," because of their vanity "there would certainly be War before there could be any Agreement among them" ( $F B$ II, p. 136). Mandevillian exchange can be seen as an outcome and not as the origin of commercial society, ${ }^{47}$ which can, rather, be the case of exchange driven by the third form of self-love: the pleasure of deserved approval.

The savages described by Mandeville come into conflict even if no material interest is at stake. Those described by Smith, instead, tend in any case to come to agreement and to engage in exchange: "In a tribe of hunters or shepherds a particular person makes bows and arrows, for example, with more readiness and dexterity than any other. He frequently exchanges them for cattle or for venison with his companions; and he finds at last that he can in this manner get more cattle and venison, than if he himself went to the field to catch them" (WN I.ii.4; emphasis added).

\footnotetext{
${ }^{43}$ See the case of the two sugar merchants in Mandeville's Fable (FB I, p. 50)

${ }^{44}$ Smith associates Mandeville's thought with mercantilism (see Smith [1763?] 1978, p. 576; see also Hurtado Prieto 2006). For the relationship in Smith between "natural" and "violent" movements, see Pack and Schliesser (2018). On Smith and the mercantile system, see Skinner (2009).

${ }^{45}$ Smith directly attacks the mercantile empire (see WN IV.vii.c.63). For a discussion of Smith on empire, see Pitts (2005) and van de Haar (2013). On inequalities in commercial society due to mercantilism, see Rasmussen (2008, p. 106).

${ }_{46}$ On Mandeville, Smith, and money, see Hurtado Prieto (2006).

${ }^{47}$ Confirmation can be found in Gerschlager (2001, 2002). She links self-deceit to partiality (2001, pp. $32-$ 35), and assumes that in exchange an agent "is not able to look impartially at himself or herself and others," and so in $W N$ "it is not self-love" that is the motive for exchange but delusions following from it (2002, pp. 16-17). She also explains self-deceit through Smith's parable of the "poor man's son" (TMS IV.1) and the economic differences among people, and argues that "without existing difference, e.g. between riches and poverty, Smith's parable would make no sense at all, as (self-)deception would not exist" (2002, p. 18). Thus, the unfair exchange she describes cannot take place in the early and rude state described by Smith, where people are "equal in fortune" (WN V.i.b.8).
} 
The savages of Smith's account first exchange and only subsequently realize that in this way they are able to obtain more goods than they otherwise would if they had to do everything by themselves. This means that they frequently exchange, although it takes some time to appreciate the advantage. ${ }^{48}$ In other words, they frequently exchange the fruits of their labor for goods that nevertheless they still think they have to procure by themselves. Those who make bows and arrows with more readiness and dexterity than anyone else exchange them for cattle and venison even if they think that in any case they have to go "to the field to catch them" and that in the end they will not have more cattle and venison thanks to the exchange. Thus, if they believe they will obtain nothing more than they can obtain by themselves working for their needs, the interested motive of obtaining more goods cannot be the reason why they should want to engage frequently in exchange. ${ }^{49}$ This also applies to the hypothesis of a "moderate self-love," understood as self-interest and not as selfishness (Young 1997; Witztum 1998; Walraevens 2010). Otherwise, this would mean that the savages described by Smith exchange because they are able to foresee the advantages of the division of labor and not because they have a natural propensity to exchange, beyond any consideration of such utility. But this is not the hypothesis Smith starts from in his explanation of the origin of the division of labor: "This division of labour, from which so many advantages are derived, is not originally the effect of any human wisdom, which foresees and intends that general opulence to which it gives occasion" (WN I.ii.1; see also Pack and Schliesser 2018). This is also why Smith introduces a natural propensity to exchange in his argument.

In Smith's account, exchange does not come about through calculation of the advantages of division of labor, to the extent that in his $L J$, explaining this point, Smith refers to individuals that "at first make presents" to their neighbors and "in return get presents" ( $L J$ B, p. 220). In this way, they realize how advantageous these practices can be, and so begin to divide labor amongst themselves (see Young 1997, pp. 58-62). However, in $W N$ he leaves the matter of gifts behind, to go on directly to exchanges between savages.

The difference between reciprocal gifts and exchange is that the rules that apply to gratitude and generosity are "vague and indeterminate" (TMS III.6.9) and might not necessarily lead to the decision to specialize, as is the case when frequent exchanges have been made, offering the savage "the certainty of being able to exchange all that surplus part of the produce of his own labour" (WN I.ii.3). Our gratitude, Smith observes, need not necessarily correspond precisely to the value of the good offices received from another: "That as soon as we can we should make a return of equal, and if possible of superior value to the services we have received, would seem to be a pretty plain rule, and one which admitted of scarce any exceptions. Upon the most superficial examination, however, this rule will appear to be in the highest degree loose and inaccurate, and to admit of ten thousand exceptions" (TMS III.6.9).

\footnotetext{
${ }^{48}$ Regard for their own interest does not drive them to exchange, but to specialize after frequent exchanges: "From a regard to his own interest, therefore, the making of bows and arrows grows to be his chief business, and he becomes a sort of armourer" (WN I.ii.3).

${ }^{49}$ See, on the other hand, for example, Hollander, who states that for Smith, "individuals, even in primitive society, are motivated by self-interest in the narrow sense of wealth accumulation" and thus the origin of propensity to exchange lies in primitive man's perception that "by means of exchange his well-being is increased" (1977, pp. 140-141). See also Walraevens (2010, p. 27).
} 
Moreover, exacting gratitude by force would be even more improper than lack of gratitude (see TMS II.ii.1.3). Instead, we can always decide to withhold our good offices when the other party does not show the appreciation of them that we consider fitting. The other can demonstrate this fair evaluation by offering us in exchange something we consider to be of equal value.

Exchanging before realizing its advantageousness for obtaining more goods means seeking another type of gratification-for example, the pleasure we may have in seeing our services appreciated by others, to the extent that they are prepared to give something they have of equal value in exchange. ${ }^{50}$ At the same time, the gratification of others comes from the fact that we are also prepared to accept their services in exchange for ours. In this way exchange is accounted for even in the absence of material interests, without having to fall back on reciprocal benevolence.

Self-love as the desire for deserved approval helps us to explain exchange not only in commercial society, but also - in contrast with non-tuism and the desire for the others' approval - in the early and rude state, constituting grounds for us to account for the propensity to exchange that gives rise to the division of labor and the process leading to commercial society.

\section{CONCLUSION}

In this article, I have put forward an interpretation of self-love as the desire for deserved approval that can provide an explanation of the act of exchange in $W N$ alternative to those based on non-tuism and the approval of the others. With the interpretation proposed here, exchange in $W N$ can be seen not necessarily as a means to obtain as much as possible from others, but as a means through which individuals can find recognition on the part of others of the approval they deserve according to any impartial spectator.

In $T M S$ we find not only the love of praise and love of praiseworthiness as such but also love of deserved praise. For Smith these desires represent three different forms of self-love. While the first two correspond to opposite poles, it is the third that Smith takes to be the most representative. Unlike Wicksteed's idea of non-tuism, deserved approval as motive for exchange takes into account the interests of both parties in exchange, aiming at that equivalence by virtue of which the deserved praise of each party can be recognized. In this kind of exchange, we try to persuade the others that we really deserve their praise. The article argues that it is this desire, connected to the propensity to exchange, that, according to Smith, lies at the origin of speech. This interpretation can also account for exchange in the primitive state, when there is no evidence of the advantages to be obtained from the division of labor. The possibility for non-tuism is not denied, or that of Mandevillian exchange, which Smith associates with the mercantile system. However, non-tuism and love of praise can hardly be considered to lie at the origin of the process leading to division of labor and commercial society, as instead could be the case of self-love as the desire for the others' deserved approval.

\footnotetext{
${ }^{50}$ On Smith seeing savages as being endowed with the impartial spectator, see Bee (2018 and 2021) and Bee and Paganelli (2019).
} 


\section{REFERENCES}

Aspromourgos, Tony. 2009. The Science of Wealth: Adam Smith and the Framing of Political Economy. London: Routledge.

Bee, Michele. 2014. "The Love of One's Self. The Adam Smith Problem Explained to Myself.” IEPHI Working Paper Series n. 60. Lausanne: University of Lausanne.

—. 2018. "Wealth and Sensibility. The Historical Outcome of Better Living Conditions for All According to Adam Smith." European Journal of the History of Economic Thought 25 (3): 473-492. - 2021. "Exploring the Continuity in Adam Smith's Thought: Chapter II (Part V) of The Theory of Moral Sentiments." The Adam Smith Review, 12: 313-328.

Bee, Michele, and Maria Pia Paganelli. 2019. "Adam Smith, Anti-Stoic.” History of European Ideas 45 (4): 572- 584.

Berry, Christopher J. 1974. “Adam Smith's Considerations on Language.” Journal of the History of Ideas 35 (1): $130-138$.

Brennan, Geoffrey, and James Buchanan. 1981. "The Normative Purpose of Economic 'Science': Rediscovery of an Eighteenth Century Method.” International Review of Law and Economics I: 155-166.

Brennan, Geoffrey, and Daniel D. Moseley. 2013. "Economics and Ethics." In Hugh LaFollette, ed., The International Encyclopedia of Ethics. Hoboken: Blackwell Publishing, pp. 1552-1578.

Broadie, Alexander. 2006. "Sympathy and the Impartial Spectator.” In, K. Haakonssen, ed., The Cambridge Companion to Adam Smith. Cambridge: Cambridge University Press, pp. 158-188.

Brown, Vivienne. 1991. "Signifying Voices: Reading the 'Adam Smith Problem."' Economics and Philosophy 7 (2): 187-220.

- 1994a. Adam Smith's Discourse: Canonicity, Commerce, and Conscience. London: Routledge. . 1994b. "Higgling: The Language of Markets in Economic Discourse." In N. de Marchi and M. Morgan, eds., Higgling: Transactors and Their Markets in the History of Economics. Annual Supplement to History of Political Economy, Vol. 26. Duke University Press, pp. 66-93.

- 1997. "Dialogism, the Gaze, and the Emergence of Economic Discourse." New Literary History 28 (4): 697-710.

- 2016. "The Impartial Spectator and Moral Judgment." Econ Journal Watch 13 (2): 232-248.

Bruni, Luigino. 2006. Civil Happiness. Economics and Human Flourishing in Historical Perspective. London: Routledge.

Darwall, Stephen. 1988. "Self-Deception, Autonomy, and Moral Constitution.” In B. P. McLaughlin and A. O. Rorty, eds., Perspectives on Self-Deception. Berkeley: University of California Press, pp. 407-430.

- 2004. "Equal Dignity in Adam Smith." The Adam Smith Review 1: 129-134.

. 2006. The Second-Person Standpoint: Morality, Respect, and Accountability. Cambridge, MA: Harvard University Press.

De Jonge, Jan. 2012. Rethinking Rational Choice Theory: A Companion on Rational and Moral Action. Basingstoke: Palgrave Macmillan.

Dellemotte, Jean. 2005. "Sympathie, desir d'améliorer sa condition et penchant à l'échange." Cahiers d'économie politique 48: 51-78.

Diatkine, Daniel. 2010. "Vanity and the Love of System in Theory of Moral Sentiments." European Journal of the History of Economic Thought 17 (3): 383-404.

Drakopoulos, Stavros A. 2011. "Wicksteed, Robbins and the Emergence of Mainstream Economic Methodology." Review of Political Economy 23 (3): 461-470.

Dupuy, Jean-Pierre. 2006. "Invidious Sympathy in The Theory of Moral Sentiments." The Adam Smith Review 2: 98-123.

Fleischacker, Samuel. 1999. A Third Concept of Liberty. Princeton: Princeton University Press.

- 2004. On Adam Smith's "Wealth of Nations": A Philosophical Companion. Princeton: Princeton University Press. 
2011. "True to Ourselves? Adam Smith on Self-Deceit." The Adam Smith Review 6: 75-92.

Fontaine, Philippe. 1997. "Identification and Economic Behaviour: Sympathy and Empathy in Historical Perspective." Economics and Philosophy 13 (2): 261-280.

- 2000. "Making Use of the Past: Theorists and Historians on the Economics of Altruism." European Journal of the History of Economic Thought 7 (3): 407-422.

Force, Pierre. 2003. Self-Interest before Adam Smith: A Genealogy of Economic Science. Cambridge: Cambridge University Press.

Forman-Barzilai, Fonna. 2010. Adam Smith and the Circles of Sympathy: Cosmopolitanism and Moral Theory. Cambridge: Cambridge University Press.

Garegnani, Pierangelo. 1983. "The Classical Theory of Wages and the Role of Demand Schedules in the Determination of Relative Prices." American Economic Review 73 (2): 309-313.

Garnett, Robert F. 2017. “Adam Smith's Oikeiōsis Revisited.” The Adam Smith Review, 10: 73-91.

Gerschlager, Caroline. 2001. "Is (Self-)Deception an Indispensable Quality of Exchange? A New Approach to Adam Smith's Concept." In C. Gerschlager, ed., Expanding the Economic Concept of Exchange. Boston: Springer, pp. 27-51.

- 2002. "Adam Smith and Feminist Perspectives on Exchange." In C. Gerschlager and M. Mokre, eds., Exchange and Deception: A Feminist Perspective. Boston: Springer, pp. 13-26.

Griswold, Charles L., Jr. 1999. Adam Smith and the Virtues of Enlightenment. Cambridge: Cambridge University Press.

- 2017. Jean-Jacques Rousseau and Adam Smith. A Philosophical Encounter. London: Routledge.

— 2018. "Being and Appearing: Self-falsification, Exchange and Freedom in Rousseau and Adam Smith.” In M. P. Paganelli, D. C. Rasmussen, and C. Smith, eds., Adam Smith and Rousseau: Ethics, Politics, Economics. Edinburgh: Edinburgh University Press, pp. 109-123.

Haakonssen, Knud. 1981. The Science of a Legislator: The Natural Jurisprudence of David Hume and Adam Smith. Cambridge: Cambridge University Press.

Hanley, Ryan Patrick. 2009. Adam Smith and the Character of Virtue. Cambridge: Cambridge University Press.

Heath, Eugene. 2013. "Adam Smith and Self-Interest.” In C. Berry, M. P. Paganelli, and C. Smith, eds., The Oxford Handbook of Adam Smith. Oxford: Oxford University Press, pp. 241-264.

Herzog, Lisa. 2013. Inventing the Market: Smith, Hegel, and Political Theory. Oxford: Oxford University Press.

Hirschman, Albert O. 1977. The Passions and the Interests: Political Arguments for Capitalism before Its Triumph. Princeton: Princeton University Press.

Hollander, Samuel. 1977. "Adam Smith and the Self-Interest Axiom.” Journal of Law and Economics 20 (1): 133-152.

Hundert, Edward J. 1994. The Enlightenment's Fable: Bernard Mandeville and the Discovery of Society. Cambridge: Cambridge University Press.

_ 2003. "Mandeville, Rousseau and the Political Economy of Fantasy." In M. Berg and E. Eger, eds., Luxury in the Eighteenth Century: Debates, Desires and Delectable Goods. Basingstoke: Palgrave, pp. $28-40$.

Hurtado Prieto, Jimena. 2004. "Bernard Mandeville's Heir: Adam Smith or Jean Jacques Rousseau on the Possibility of Economic Analysis." European Journal of the History of Economic Thought 11 (1): $1-31$.

- 2006. “The Mercantilist Foundations of 'Dr Mandeville's Licentious System.'” In Leonidas Montes and Eric Schliesser, eds., New Voices on Adam Smith. London: Routledge, pp. 221-246.

Kalyvas, Andreas, and Ira Katznelson. 2001. "The Rhetoric of the Market: Adam Smith on Recognition, Speech, and Exchange." Review of Politics 63 (3): 549-580.

Kerkhof, Bert. 1995. "A Fatal Attraction? Smith's 'Theory of Moral Sentiments' and Mandeville's 'Fable."” History of Political Thought 16 (2): 219-233. 
Khalil, Elias L. 1990. "Beyond Self-Interest and Altruism: A Reconstruction of Adam Smith's Theory of Human Conduct." Economics and Philosophy 6 (2): 255-273.

Lewis, Thomas J. 2000. "Persuasion, Domination and Exchange: Adam Smith on the Political Consequences of Markets.” Canadian Journal of Political Science 33 (2): 273-289.

Luban, Daniel. 2012. "Adam Smith on Vanity, Domination, and History.” Modern Intellectual History 9 (2): 275-302.

Macfie, Alexander L. 1967. The Individual in Society: Papers on Adam Smith. London: Routledge.

Mandeville, Bernard. [1732] 1988. Fable of the Bees or private vices, publick benefits. Two volumes (FB I and $F B$ II). With a Commentary Critical, Historical, and Explanatory by F. B. Kaye. Indianapolis: Liberty Fund.

McCloskey, Deirdre N. 2006. The Bourgeois Virtues. Ethics for an Age of Commerce. Chicago: The University of Chicago Press.

McHugh, John. 2016. "Ways of Desiring Mutual Sympathy in Adam Smith's Moral Philosophy." British Journal for the History of Philosophy 24 (4): 614-634.

. 2018. "Pursuing Sympathy without Vanity: Interpreting Smith's Critique of Rousseau through Smith's Critique of Mandeville.” In M. P. Paganelli, D. C. Rasmussen, and C. Smith, eds., Adam Smith and Rousseau: Ethics, Politics, Economics. Edinburgh: Edinburgh University Press, pp. 109-123.

Mehta, Pratap Bhanu. 2006. "Self-Interest and Other Interests." In K. Haakonssen, ed., The Cambridge Companion to Adam Smith. Cambridge: Cambridge University Press, pp. 246-269.

Naldi, Nerio. 2013. "Adam Smith on Value and Prices.” In C. Berry, M. P. Paganelli, and C. Smith, eds., The Oxford Handbook of Adam Smith. Oxford: Oxford University Press, pp. 290-306.

Otteson, James R. 2002. "Adam Smith's First Market: The Development of Language." History of Philosophy Quarterly 19 (1): 65-86.

Pack, Spencer J. 1991. Capitalism as a Moral System. Adam Smith's Critique of the Free Market Economy. Cheltenham: Edward Elgar.

Pack, Spencer J., and Eric Schliesser. 2018. “Adam Smith, Natural Movement and Physics.” Cambridge Journal of Economics 42: 505-521.

Paganelli, Maria Pia. 2008. "The Adam Smith Problem in Reverse: Self-Interest in The Wealth of Nations and The Theory of Moral Sentiments." History of Political Economy 40 (2): 365-382.

- 2010. "The Moralizing Role of Distance in Adam Smith: The Theory of Moral Sentiments as Possible Praise of Commerce." History of Political Economy 42 (3): 425-441.

Paganelli, Maria Pia, Dennis C. Rasmussen, and Craig Smith, eds. 2018. Adam Smith and Rousseau: Ethics, Politics, Economics. Edinburgh: Edinburgh University Press.

Pitts, Jennifer. 2005. A Turn to Empire: The Rise of Imperial Liberalism in Britain and France. Princeton: Princeton University Press.

Raphael, David D. 2007. The Impartial Spectator: Adam Smith's Moral Philosophy. Oxford: Clarendon Press.

Raphael, David D., and Alexander L. Macfie. 1976. "Introduction.” In Adam Smith, The Theory of Moral Sentiments. Oxford: Oxford University Press, pp. 1-51.

Rasmussen, Dennis C. 2008. The Problems and Promise of Commercial Society: Adam Smith's Response to Rousseau. University Park: Penn State University Press.

Robbins, Lionel. 1998. A History of Economic Thought: The LSE Lectures. Princeton: Princeton University Press.

Roncaglia, Alessandro. 2005. The Wealth of Ideas. A History of Economic Thought. Cambridge: Cambridge University Press.

Rothschild, Emma. 2001. Economic Sentiments: Adam Smith, Condorcet, and the Enlightenment. Cambridge, MA: Harvard University Press.

Rousseau, Jean-Jacques. [1755] 2008. Discours sur l'origine et les fondements de l'inégalité parmi les hommes. Paris: Flammarion.

Skinner, Andrew S. 1992. "Adam Smith: Ethics and Self-Love.” In Peter Jones and Andrew Skinner, eds., Adam Smith Reviewed. Edinburgh: Edinburgh University Press, pp. 142-167. 
2009. "The Mercantile System.” In Jeffrey T. Young, ed., Elgar Companion to Adam Smith. Cheltenham: Edward Elgar, pp. 261-276.

Smith, Adam. [1756] 1980. "A Letter to the Authors of the Edinburgh Review." In Adam Smith, Essays on Philosophical Subjects. Oxford: Oxford University Press, pp. 242-256.

- [1759] 1976. The Theory of Moral Sentiments (TMS). Oxford: Oxford University Press.

. [1762-1766] 1978. Lectures on Jurisprudence ( $L J$ A and $L J$ B). Oxford: Oxford University Press.

. [1763?] 1978. "Early Draft of The Wealth of Nations." In Adam Smith, Lectures on Jurisprudence.

Oxford: Oxford University Press, pp. 562-581.

. [1776] 1976. An Inquiry into the Nature and Causes of the Wealth of Nations (WN). Two volumes.

Oxford: Oxford University Press.

1983. Lectures on Rhetoric and Belles Lettres. Oxford: Oxford University Press.

Steedman, Ian. 1989. "Rationality, Economic Man and Altruism in P. H. Wicksteed's Common Sense of Political Economy." In Ian Steedman, From Exploitation to Altruism. London: Polity Press, pp. 185-204.

—. 2010. "Keeping Faith, Losing Faith: Religious Belief and Political Economy." European Journal of the History of Economic Thought 17 (2): 345-348.

Stigler, George. 1971. "Smith's Travels on the Ship of State." History of Political Economy 3 (2): 265-277.

Swearingen, Jan C. 2013. "Adam Smith on Language and Rhetoric: The Ethics of Style, Character, and Propriety.” In C. Berry, M. P. Paganelli, and C. Smith, eds., The Oxford Handbook of Adam Smith. Oxford: Oxford University Press, pp. 159-174.

Tolonen, Mikko S. 2013. Mandeville and Hume: Anatomists of Civil Society. Oxford: University of Oxford. Van de Haar, Edwin. 2013. "Adam Smith on Empire and International Relations." In C. Berry, M. P. Paganelli, and C. Smith, eds., The Oxford Handbook of Adam Smith. Oxford: Oxford University Press, pp. 417-439.

Verburg, Rudi. 2000. "Adam Smith's Growing Concern on the Issue of Distributive Justice." European Journal of the History of Economic Thought 7 (1): 23-44.

.2015. "Bernard Mandeville's Vision of the Social Utility of Pride and Greed." European Journal of the History of Economic Thought 22 (4): 662-691.

Viner, Jacob. [1972] 2015. The Role of Providence in the Social Order: An Essay in Intellectual History. Princeton: Princeton University Press.

Walraevens, Benoît. 2010. "Adam Smith's Economics and the Lectures on Rhetoric and Belles Lettres: The Language of Commerce." History of Economic Ideas 18 (1): 11-32.

. 2014. "Vertus et justice du marché chez Adam Smith." Revue économique 65 (2): 419-38.

2019. "Vanité, orgueil et self-deceit : l'estime de soi excessive dans la Théorie des Sentiments Moraux d'Adam Smith." Revue de philosophie économique 20 (2): 3-39.

Weinstein, Jack Russell. 2013. Adam Smith's Pluralism. Rationality, Education, and the Moral Sentiments. New Haven: Yale University Press.

Wells, Thomas, and Johan Graafland. 2012. "Adam Smith's Bourgeois Virtues in Competition.” Business Ethics Quarterly 22 (2): 319-350.

Wicksteed, Philip H. 1910. The Common Sense of Political Economy, including a Study of the Human Basis of Economic Law. London: Macmillan and Co.

Wilson, Thomas. 1976. "Sympathy and Self-Interest." In Thomas Wilson and Andrew S. Skinner, eds., The Market and the State: Essays in Honour of Adam Smith. Oxford: Oxford University Press, pp. 73-99.

Winch, Donald. 1978. Adam Smith's Politics: An Essay in Historiographic Revision. Cambridge: Cambridge University Press.

Witztum, Amos. 1997. "Distributive Considerations in Smith's Conception of Economic Justice." Economics \& Philosophy 13 (2): 241-259.

- 1998. "A Study into Smith's Conception of the Human Character: Das Adam Smith Problem Revisited." History of Political Economy 30 (3): 489. 
Young, Jeffrey T. 1985. "Natural Price and the Impartial Spectator: A New Perspective on Adam Smith as a Social Economist.” International Journal of Social Economics 12 (6/7): 118-121.

. 1986. "The Impartial Spectator and Natural Jurisprudence: An Interpretation of Adam Smith's Theory of the Natural Price." History of Political Economy 18 (3): 365-382.

- 1995. "Natural Jurisprudence and the Theory of Value in Adam Smith." History of Political Economy 27 (4): 755-773.

. 1997. Economics as a Moral Science: The Political Economy of Adam Smith. Cheltenham: Edward Elgar.

- 2001. “Adam Smith's Two Views of the Market.” In P. L. Porta, R. Scazzieri, and A. S. Skinner, eds., Knowledge, Social Institutions and the Division of Labour. Cheltenham: Edward Elgar, pp. 95-110. 